\title{
Subjective Well-Being and the 2008 Recession in European Regions: The Moderating Role of Quality of Governance
}

\author{
Efstratia Arampatzi ${ }^{1}$ - Martijn J. Burger ${ }^{1} \cdot$ Spyridon Stavropoulos $^{1}$. \\ Frank G. van Oort ${ }^{1}$
}

Received: 15 October 2018 / Accepted: 1 March 2019 / Published online: 15 April 2019

(C) The Author(s) 2019

\begin{abstract}
How can we explain why some regions experienced large decreases in subjective wellbeing during the 2008 recession, while in other regions, the changes were only very modest? Building on the literature on resilience in subjective well-being during periods of crisis, this article explores a related but undervalued factor that moderates the localized relationship between macroeconomic developments and life evaluation: regional quality of governance. We use individual-level data on life satisfaction and personal information taken from Eurobarometer for 89 European regions in the EU-28 for the period of 2005-2014, combined with macroeconomic variables and regional quality of governance data to test for the hypothesized moderating effect of quality of governance. The results demonstrate that increased regional unemployment and financial stress have a less aggravating effect on subjective well-being in regions characterized by a high quality of governance. These results support the capacity of quality of governance to buffer the negative effects of adverse macroeconomic conditions, most likely through generating trust and providing a safety net.
\end{abstract}

Keywords Subjective well-being · Economic crisis · Europe · Quality of governance

\section{Introduction}

Over the past few years, there has been increasing attention to subjective well-being, also known as happiness or life satisfaction (Veenhoven 1984), in public policy and popular culture. In 2012, the General Assembly of the United Nations adopted a

Martijn J. Burger

mburger@ese.eur.nl

1 Erasmus School of Economics, Erasmus University Rotterdam, H12-11 / M5-37, Burg. Oudlaan 50, 3062 PARotterdam, The Netherlands 
resolution that governments should try to increase the subjective well-being of their citizens. Along these lines, one of the key objectives of the 2020 European Strategy (European Commission 2010) is the promotion of subjective well-being. However, subjective well-being as a policy issue is not confined to central governments, in that several regional and local authorities have also started to implement subjective wellbeing in policy (Burger 2015; Morrison and Weckroth 2018). At the same time, the increasing public appreciation of subjective well-being is evidenced-amongst others - by the widespread media attention to rankings of places on the 'happiness ladder' as well as the fact that subjective well-being is currently rated the second most important component for a better life in the OECD Better Life Index, mattering more than topics such as education, income, and civic engagement.

Several European regions experienced substantial declines in subjective well-being during the Great Recession that started in 2008. Particularly, regions in Greece, Spain, Italy and Portugal suffered from substantial declines in subjective well-being between 2008 and 2013 (see also Eurobarometer). For instance, whereas in 2005, 63\% of the adult population in Athens considered themselves fairly satisfied or very satisfied, this figure had dropped to $43 \%$ by 2014 , with a low of $34 \%$ in 2012 . However, in all WestEuropean regions, the decrease in subjective well-being was limited and in most cases negligible during the Great Recession, even in West-European countries and regions that were hard hit during the economic crisis. Most notably, subjective well-being did not decrease in Iceland (Gudmundsdottir 2013) after the collapse of the banking system, while in Ireland, the share of the population who considered themselves fairly or very satisfied with life only slightly decreased, from $91 \%$ in 2005 to $89 \%$ in 2014 , with a low of $83 \%$ in 2013.

How can we explain why some regions experienced large decreases in subjective well-being during the crisis, while in other regions, the changes were only very modest? On the one hand, differences in subjective well-being development between regions can be explained by uneven regional development in unemployment rates and income losses. In Ireland, for example, although unemployment rates increased to almost $15 \%$ during the Great Recession, it would be fair to say that the unemployed experienced less hardship than Andalusia and the Canary Islands, where unemployment rates increased to over $30 \%$. At the same time, research shows that during the most recent recession of 2008, the Mediterranean countries experienced much larger declines in subjective well-being than what would be explained or even predicted from losses in income and unemployment rates (World Happiness Report (WHR), 2013; Helliwell et al. 2014). ${ }^{1}$

Indeed, some regions appear to be more resilient in regard to subjective well-being than other countries and regions. ${ }^{2}$ Research has shown that unexpectedly large changes in subjective well-being are conditional upon other economic and social factors (WHR 2013; Gonza and Burger 2017; Helliwell et al. 2014; Bjørnskov 2014; Mikucka et al. 2017). More specifically, institutional and social trust (Helliwell et al. 2014), social capital (Gudmundsdottir 2013), and the presence of unemployment support

\footnotetext{
${ }^{1}$ Indeed, cross-country comparisons show that the international differences in subjective well-being during the Great Recession are explained by other factors than economic outcomes per se (WHR, 2013).

${ }^{2}$ In addition, there has been a literature that examines how personality affects resilience in times of economic crisis. However, a discussion of this literature (see e.g., Arampatzi et al. 2018) is beyond the scope of this article.
} 
programmes and employment protection legislation (Morgan 2018) have been identified as factors that can alleviate the negative impact of an economic crisis on subjective well-being.

Building on the literature on resilience in subjective well-being during periods of crisis, this article explores a related but understudied factor that moderates the localized relationship between macroeconomic developments and life evaluation: regional quality of governance. Europe is a heterogeneous continent with a significant large variation in quality of governance between regions. ${ }^{3}$ The positive association between quality of governance and subjective well-being has been well-established in the literature on subjective well-being (Ott 2010; Alvarez-Diaz et al. 2010; Helliwell and Huang 2008). Good governance entails numerous characteristics that are associated with subjective well-being, such as inclusive law-making and ensuring that policy-making procedures are fair (Frey and Stutzer 2000a; Helliwell et al. 2015), political participation (Frey and Stutzer 2000b; Dorn et al. 2007), and fighting corruption (Tay et al. 2014). In this article, we argue that good regional (and national) governance can also provide a buffer against the negative impact of the crisis through generating trust and providing a safety net. We use individual-level data on life satisfaction and personal information taken from Eurobarometer for 28 European countries for the period of 2005-2014, combined with macroeconomic variables and regional quality of governance data to test for the hypothesized moderating effect of quality of governance.

This paper adds to the existing literature in two distinct ways. First, it is, to the best knowledge of the authors, the first paper to explore the moderating role of regional quality of governance as an alleviating factor in response to the Great Recession in terms of subjective well-being. Second, our study explores these data on quality of governance at the regional level (NUTS 1) in Europe by using the combined Quality of Governance Index (see also Rodríguez-Pose and Di Cataldo 2015; Charron et al. 2011; Charron et al. 2014). This links to the article by Cortinovis et al. (2017), who show that formal institutions, like quality of governance, are necessary conditions for economic development, and for informal institutions like trust and social capital to interact with development regionally.

The remainder of the paper is organized as follows: Section 2 gives an overview of the findings on economic crises and subjective well-being and introduces quality of governance and its relationship to subjective well-being. Section 3 outlines the data and methodology used. Section 4 presents the results, and Section 5 concludes.

\section{The Great Recession in Europe and Subjective Well-Being}

\section{National and Regional Variations}

Over the past few years, several studies have assessed the effects of economic crises on subjective well-being (e.g., Frey and Stutzer 2002; Di Di Tella et al. 2003; Arampatzi et al. 2015; O’Connor 2017). In these studies, joblessness and loss of income are found

\footnotetext{
${ }^{3}$ European agencies are pioneers in the measurement of quality of governance focused on the regional level, with the first attempts to measure regional variation in the quality of governance in Europe taking place in 2010 with the initiative of European Commission and at the University of Gothenburg (Charron et al. 2011; Charron et al. 2014).
} 
to be among the most important factors affecting the subjective well-being of individuals in times of economic crisis (Di Tella et al. 2003). However, the effects of economic crises are not limited to the subjective well-being of people who experience job loss or income decrease (Deaton 2011; Arampatzi et al. 2015; O’Connor 2017). Controlling for individual unemployment and income, Di Di Tella et al. (2003) found a negative effect of macroeconomic unemployment and economic decline on subjective wellbeing. Likewise, increasing unemployment rates during the Great Recession affected the subjective well-being of the employed population, especially of those employees who experienced financial distress (Arampatzi et al. 2015).

Notwithstanding the considerable efforts to examine how subjective well-being fluctuates with macroeconomic changes, it is fair to say that the effect of the Great Recession on subjective well-being is not homogeneous across countries (Deaton 2011; Gudmundsdottir 2013; O'Connor 2017; WHR 2013). The effect of the Great Recession on subjective well-being in the United States was only short-lived (Deaton 2011), while the collapse of the banking system in Iceland and consequent unemployment and income losses were not found to be consistently associated with lower happiness levels (Gudmundsdottir 2013). In contrast, the 2013 World Happiness Report documented substantial losses in life evaluation during the economic downfall in Europe after 2007. Using data from Gallup World Poll, it was found that in the European Union, the Mediterranean countries in particular reported sizable declines in subjective well-being, the magnitude of which could not be explained by macroeconomic conditions alone. Greece ranked second in the worldwide list, with the largest declines in well-being between 2005 and 2012, followed by Spain, Italy and Portugal in the sixth, eighth and twentieth positions, respectively (WHR 2013).

At the same time, there were considerable differences in subjective well-being developments within these countries. For instance, people in the Cataluña and Centro regions of Spain experienced hardly any decline in subjective well-being during the Great Recession, while the Northwest of Germany (Niedersachsen and Hamburg) experienced declines in subjective well-being when the rest of Germany was experiencing an increase in subjective well-being. Likewise, macroeconomic developments and quality of governance can also vary substantially between regions within countries (Charron et al. 2014), especially in countries such as Germany (East vs. West) and Italy (North vs. South). Formal institutions like property rights, rule of law, competition monitoring and contractual agreements, are recognised as essential for economic growth and innovation (Acemoglu and Johnson 2005), mostly referring to the coordination and uncertainty-reduction effects of formal institutions. When political authorities set clear rules, are prevented from taking advantage of their positions (like unduly extracting benefits from economic activities), and provide incentives stimulating the activity of economic actors, they can contribute to the growth and dynamism of an economy (Acemoglu and Robinson 2012). Within a set of clear and inclusive rights and rules, individuals are able to pursue their economic interests. In such an environment of lower risks and uncertainties, well-functioning governments may implement policies making especially local actors better able to take advantage of the inflow of ideas, products and knowledge relating to region-specific specializations (Sterlacchini 2008; Charron et al. 2014). While research on formal institutions is conducted primarily at the country level, even more pronounced arguments apply to the regional level. Significant within-country variations in the quality of formal institutions are expected to be 
important for economic development in interaction with well-being (Rodriguez-Pose, Rodríguez-Pose 2013). Regions characterized by quality government institutions are found to perform better in terms of socio-economic development (Charron et al. 2014), growth and convergence (Arbia et al. 2010) and innovation (Crescenzi and RodríguezPose 2013).

\section{The Mitigating Effect of Regional Quality of Governance}

The idea that there are certain conditions that can mitigate or intensify crisis-related costs in terms of social-economic development and well-being is highly relevant for a body of literature that has examined why the crisis had a more aggravating impact on the happiness of certain people, regions and countries (e.g., Bjørnskov 2014; Helliwell et al. 2014; Morgan 2018; Carr and Chung 2014; Wulfgramm 2014).

Among the moderators, the quality of the social fabric has been found to alleviate the impact of an economic crisis (WHR 2013). Helliwell et al. (2014) found that communities with higher social capital and trust were happier during the crisis. Gudmundsdottir (2013) suggests that in the case of Iceland, the effect of the economic crisis was limited, a phenomenon that can be explained by the good social relationships of its citizens. Along similar lines, Mikucka et al. (2017) found that in the long run, economic growth improves subjective well-being when social trust does not decline.

On a different note, differences in unemployment benefits between countries have been found to be a factor that moderates the relationship between poor macroeconomic conditions and subjective well-being (Morgan 2018; Carr and Chung 2014; Wulfgramm 2014). Voßemer et al. (2017) found that considerable unemployment benefits can mitigate the negative effects that unemployment has on subjective wellbeing.

This paper examines the moderating effect of good regional governance in explaining the differences in how European countries responded to the economic crisis. Substantial work has focused on the role of good governance as a determinant of subjective well-being. However, quality of governance, or what we call "good governance", is not strictly defined. Moreover, in empirical research, a large variety of indicators have been used as proxies for quality of governance, including institutional performance (Frey and Stutzer 2000b), the quality of institutions, the ideological orientation of the elected government, economic freedom (Spruk and Kešeljević 2016), the welfare state, civic rights, political participation and fairness (Stutzer and Frey 2003). In this research, we take the most comprehensive and commonly used operationalization in economics: the Quality of Governance Index (QoG) by Kaufmann et al. (2011). ${ }^{4}$ The six components developed to measure quality of governance are Government Effectiveness, Regulatory Quality, Rule of Law, Control of Corruption, Political Stability and Absence of Violence, and Voice and Accountability, which are all found to be positively related to subjective well-being. Whereas the first four elements capture the quality of delivery or responsiveness of governments in their design and

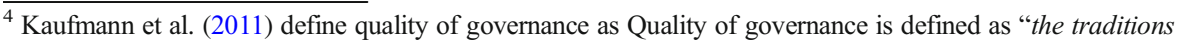
and institutions by which authority in a country is exercised. This includes (1) the process by which governments are selected, monitored and replaced (2) the capacity of a government to effectively formulate and implement sound policies and (3) the respect of its citizens and the state of institutions that govern economic and social interactions among them" (Kaufman et al. (2011), p4).
} 
delivery of services, the last two components capture democratic quality (Helliwell and Huang 2008). In our research, we focus primarily on the quality of delivery or responsiveness of governments in their design and delivery of services and we follow the literature referring on European regions (Charron et al. 2014). ${ }^{5}$

In the context of economic crises, good governance signals the ability of governments and their institutions to handle and cope with adversities. It is therefore expected that the beneficial outcomes of good governance are even more important during economic downturns. At the same time, limited attention has been given to the role of quality of governance as a mitigating factor in times of crisis, especially at the regional level. ${ }^{6}$

Regional quality of governance can be expected to have a buffering effect due to its inherent power to "protect" subjective well-being. This protective function is wellestablished in political science. In times of economic turbulence, economic instability affects the financial safety of individuals (Radcliff 2001), resulting in distress (Brenner 1977). Governments can play an important role here by protecting well-being of individuals from the 'market forces' (Radcliff 2001). In this regard, the generosity of the welfare state has been found to be positively related to both quality of governance (Rothstein et al. 2012) and life satisfaction (Ott 2010), where particularly more leftist governments and social-democratic welfare systems (Pacek and Radcliff 2008) provide more welfare benefits that are conducive to subjective well-being. Specifically, Rothstein et al. (2012) perceive quality of governance as a precondition for support of the welfare state and find that good governance is positively related to the size and generosity of the welfare state. In addition, public spending becomes more efficient with good governance (Rajkumar and Swaroop 2008). In times of crisis, this would mean that funds are more effectively allocated, such that they can alleviate the negative effects associated with the loss of income and jobs and can safeguard the quality of life in a region.

Second, good governance creates trust, which in turn can increase subjective wellbeing by promoting the feeling that 'everything will be alright'. Indicators of good governance are not strictly related to the way governments function but extend to citizens' perceptions. In that respect, institutional trust has also received considerable attention in research. Institutional trust is defined as the expected utility of institutions performing satisfactorily (Mishler and Rose 2001), and it can be considered a subjective measure of good governance. Institutional trust can be highly dependent on institutional performance, and hence, it is often suggested to be endogenous. When institutions underperform and the institutional trust of the citizens is damaged, people tend to show less-cooperative attitudes (e.g., are more likely to evade taxes; Orviska and Hudson 2003) and are generally less satisfied with their lives (Helliwell et al. (2014). In this regard, Helliwell et al. (2014) find that the decline in different types of trust, including generalized social trust and trust in institutions, could explain decreases in life evaluation that cannot be attributed to changes in GDP and unemployment in

\footnotetext{
${ }^{5}$ Following Charron et al. (2014), we use four pillars to measure QoG at the national level: Control of corruption, Rule of law, Government effectiveness, Voice and accountability.

${ }^{6}$ A notable exception is Bjørnskov (2014), who examines the role of easy market regulations and institutions as moderators that alleviate negative impacts during recessions.
} 
times of crisis. The regional context of daily urban systems and localized institutionalized labour and housing policies is highly conditioning on this process.

\section{Data and Model}

\section{Data: Dependent and Independent Variables}

Economists increasingly use subjective well-being measures as proxies for experienced utility (see, e.g., Clark and Oswald 1994; Di Tella et al. 2001; Easterlin 1974; Freeman 1978; Frey and Stutzer 2000a, b; Kahneman et al. 1997), especially due to their compliance with the idea that individuals depart from the classic utility model when it is assumed that actual choices represent preferences or expected utility. Subjective well-being can be defined as 'the degree to which an individual judges the overall quality of his/her own life-as-a-whole favorably' (Veenhoven 1984, Chapter 2). ${ }^{7}$

In our study, we primarily use the Eurobarometer survey for the period 2005-2014.

Overall, our sample consists of well over 250,000 observations for the period 20052014 for 89 regions in the EU-28 countries. Subjective well-being is measured using a 4-point scale measure of life satisfaction on the following question: "On the whole, are you very satisfied, fairly satisfied, not very satisfied, or not at all satisfied with the life you lead?" Possible answers are (1) Not at all satisfied, (2) Not satisfied, (3) Fairly satisfied, and (4) Very satisfied. This life satisfaction question is one of the most commonly used measures of subjective well-being in economics (Di Tella et al. 2003; Arampatzi et al. 2015).

In addition, respondents reported on their current unemployment status and the financial situation of their household. The latter is used as proxy for income mainly due to the lack of a real income metric at the individual or household level. Individuals are asked to rate their financial situation based on the following item: "How do you judge the current situation in each of the following? Your financial situation". Responses range from 1 to 4, where 1 is "Very good", 2 "Rather good", 3 "Rather bad" and 4 "Very bad". We use a wide set of additional individual-level information such as gender, age, education level, marital status and socio-economic characteristics as control variables (Table 1).

The individual-level data from Eurobarometer in our study are complemented with regional-level and country-level characteristics from two sources. First, we use information from Eurostat on regional (NUTS-1) unemployment rate (as a percentage of active population) and regional GDP growth for the same period. For the purpose of this paper, we account for regional positive and negative growth separately. The GDP growth rate was split into positive and negative to observe the asymmetric effect of growth, as suggested in previous studies (De Neve et al. 2017). Inflation rates are taken from the World Development Indicators of the World Bank.

\footnotetext{
${ }_{7}^{7}$ Consequently, the terms happiness and life satisfaction are often used interchangeably for subjective wellbeing as two measures of overall appraisal. As noted by Veenhoven (1984), happiness, or the affective component of subjective well-being, is determined by the overall impression of how people feel most of the time; life satisfaction, or the cognitive component of subjective well-being, incorporates a cognitive judgment of standards of living. Happiness and life satisfaction are found to be highly correlated and to behave similarly in many cases (Fordyce 1988).
} 
Table 1 Descriptive statistics: Microdata from Eurobarometer 2005-2014

\begin{tabular}{|c|c|c|c|c|c|}
\hline & (1) & (2) & (3) & (4) & (5) \\
\hline Variables & $\mathrm{N}$ & mean & sd & $\min$ & $\max$ \\
\hline Life Satisfaction & 255,374 & 2.896 & 0.804 & 1 & 4 \\
\hline Sex & 255,374 & 1.546 & 0.498 & 1 & 2 \\
\hline Age groups & 255,374 & 2.934 & 1.033 & 1 & 4 \\
\hline Marital Status & 255,374 & 1.799 & 1.044 & 1 & 5 \\
\hline Education & 255,374 & 2.232 & 1.162 & 1 & 5 \\
\hline Employment status & 255,374 & 1.949 & 0.957 & 1 & 3 \\
\hline Financial Situation of $\mathrm{hh}$ & 255,374 & 2.379 & 0.763 & 1 & 4 \\
\hline
\end{tabular}

\section{Moderator Variable: Regional Quality of Governance}

For our moderator variable, we obtained data from the University of Gothenburg on regional quality of governance and constructed the Regional Combined EQI (see Charron et al. 2014). To achieve that, we use the combined EQI Index (RodríguezPose and Di Cataldo 2015; Charron et al. 2014) for 89 regions (NUTS 1) within EU Member States. Table 2 presents the descriptive statistics of the macro variables.

The data on quality of governance are almost exclusively focused on the national level. The most widely used national-level information on quality of governance in Europe, the World Governance Indicators (WGI; Kaufmann et al. 2009), is available from the World Bank. Based on the WGI indicators and survey questions on citizens' perceptions on quality of governance ${ }^{8}$ Charron et al. (2014) measured regional quality of governance in Europe for 2010 and 2013.

The index currently constitutes the most elaborate source of quality of governance at the regional level in Europe. Unfortunately, repeated measurements of regional quality of governance are not available for years other than 2010 and 2013, a limitation that drives the general unavailability of research on good governance at the regional level. To estimate the regional quality of governance for missing years, we follow Charron et al. (2014) and Rodríguez-Pose and Di Cataldo (2015) by implementing their combined Quality of Governance Index.

To construct the combined Quality of Governance Index, we follow Charron et al. (2014) and use the four out of six pillars of quality of governance at the national level: (i) Control of Corruption, (ii) Rule of Law, (iii) Government effectiveness and (iv) Voice and Accountability. We combine these pillars with regional quality of governance data for 2010 and $2013,{ }^{9}$ applying the following estimation (Rodríguez-Pose and Di Cataldo 2015, Charron et al. 2014):

\footnotetext{
${ }^{8}$ The survey includes 34,000 respondents and addresses three questions related to perception of quality, impartiality and corruption of public services.

${ }^{9}$ Following Charron et al. (2014), we account for 4 out of 6 pillar of quality of governance. Political Stability and Regulatory Quality are therefore excluded.
} 
Table 2 Descriptive statistics of macro determinants

\begin{tabular}{llllll}
\hline & $(1)$ & $(2)$ & $(3)$ & $(4)$ & (5) \\
\hline Variables & $\mathrm{N}$ & mean & sd & Min & max \\
Regional Positive GDP Growth & 89 & 4.459 & 4.961 & 0 & 29.63 \\
Regional Negative GDP Growth & 89 & 1.241 & 3.680 & 0 & 27.59 \\
Regional Unemployment Rate & 89 & 9.096 & 4.584 & 2.7 & 35.1 \\
Inflation & 28 & 2.530 & 2.234 & -4.479 & 15.40 \\
Regional Combined QoG & 89 & 0.00221 & 0.999 & -2.686 & 1.789 \\
\hline
\end{tabular}

$$
\text { CombinedEQI } I_{\text {regionXcountryY }}=W G I_{\text {countryY }}+\left(R \operatorname{Rog}_{\text {regionXcountry } Y}-C R q o g_{\text {countryY }}\right)
$$

where Combined EQI is the final score from each region $\mathrm{X}$ or country $\mathrm{Y}$ in the EQI; $W G I$ is the national average governance score for each country Y; Rqog is each region's $\mathrm{X}$ score from the regional survey; and CRqog is the country weighted average in country $Y$ of all regions within country $Y$ from the regional survey. To make it comparable to the EQI index, we normalize the Combined Index and its components to make them range from 0 to 1. Figure 1 shows regional averages of the Combined EQI Index for selected EU regions between 2005 and 2014. More-detailed information on economic development and quality of governance scores can be found in Appendix A.

\section{Model}

To examine the moderating effect of good governance, we estimate the following reduced subjective well-being equation:

$$
\begin{aligned}
S W B_{i j t}= & b_{0}+\boldsymbol{V}^{*}+b_{1} \text { Individual }_{i j t}+b_{2} \text { RegMacroeconomic }_{j t}+b_{3} \text { Combined }_{\text {EQI }}{ }_{j t} \\
& +x_{i j}+t_{t}+\varepsilon_{i j}
\end{aligned}
$$

where $V^{*}$ is a vector of interaction effects of the following:
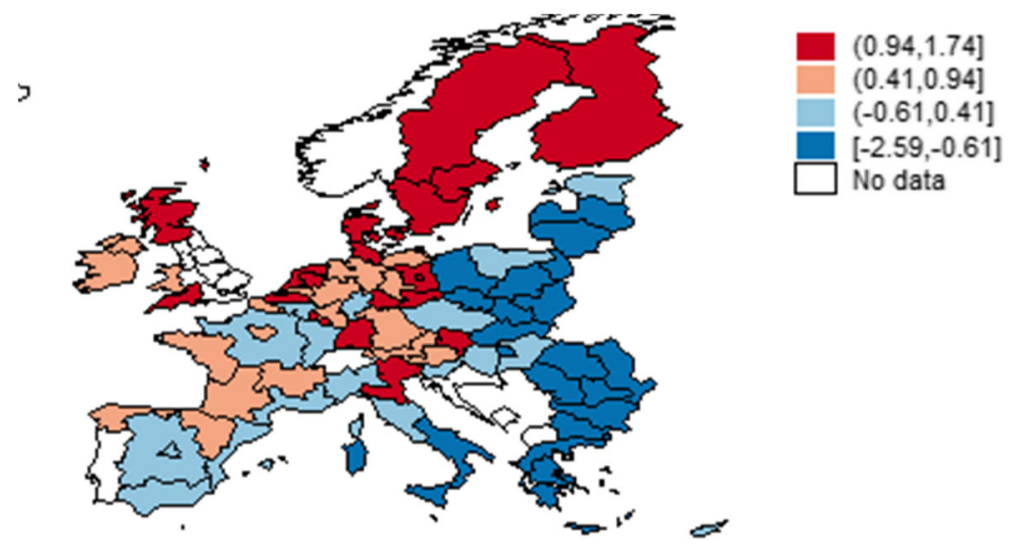

Fig. 1 Combined EQI Index in 89 EU regions, 2005-2014 Averages 


$$
\begin{aligned}
V^{*}= & b_{1}[\text { Combined EQI*RegUnemployment }]_{j t} \\
& +b_{2}[\text { Combined EQI*RegionalGDPGrowth }]_{j t}+b_{3}[\text { Combined EQI*Inflation }]_{j t} \\
& +b_{4}[\text { Combined EQI*Unemployed }]_{i j t} \\
& +b_{5}[\text { Combined EQI*Financial Situation }]_{i j t}
\end{aligned}
$$

where

$S W B_{i j t}$ is the reported subjective well-being for individual $i$ in region $j$ in year $t$. Individual $_{i j t}$ is a vector of individual characteristics - including the financial situation of the household and unemployment status, gender age, marital status, educational level for individual $i$ in region $j$ and year $t$. RegMacroeconomic $c_{j t}$ is a vector macroeconomic indicators, including regional unemployment rate, regional economic growth rate and national-level inflation. $x_{i}$ is a vector of region dummies, and $t_{t}$ is a vector of year dummies. With regard to the vector of interaction effects, the Combined EQI $I_{j t}$ is the Combined EQI Index in region $j$ in year $t$. We examine the buffering effect of quality of governance at both the individual and national level by interacting quality of governance with (1) regional unemployment rate, (2) regional positive and negative growth rates, (3) inflation, (4) individual unemployment status, and (5) financial status of the household.

\section{Results}

Given the categorical nature of our dependent variable, all models were estimated using ordered logistic regression. All of our models were estimated using cluster-robust standard errors (NUTS 1). ${ }^{10}$ Table 3 (Column 1) show the effects of regional quality of governance on life satisfaction. Controlling for region fixed effects (at the NUTS 1 level), year dummies and individual characteristics, the regional quality of governance has a positive and statistically significant effect on the probability that individuals will report higher life satisfaction levels; the higher the score is, the more satisfied individuals are. Table 3 (Column 2) differentiates between regional and national quality of governance as shown in Eq. 1. Both components are strongly and positively related to the dependent variable; life satisfaction, indicating that sub-national variations in quality of governance matter.

At the same time, we can see that adverse economic circumstances are negatively associated with individuals' subjective well-being. In line with previous literature, regional unemployment (Table 3, Column 3) and negative growth (Table 3, Column 4) are negatively associated with subjective well-being. The effects of regional unemployment remain unchanged when we condition on other factors, indicating its

\footnotetext{
${ }^{10}$ In our research, we avoid an ecological fallacy by including data that have been measured at different levels of aggregation (individual-level, regional-level, and country-level) and clustering the standard errors (Primo et al. 2007). An alternative here would be the use of multilevel models, which have elsewhere been discuss in the regional studies literature (see e.g., Van Oort et al. 2012). Comparing the two types of modelling strategies, Primo et al. (2007) have suggested that calculating clustered standard errors is a more straightforward and practical approach. We also experimented with the multilevel model, however the multilevel models did not converge.
} 


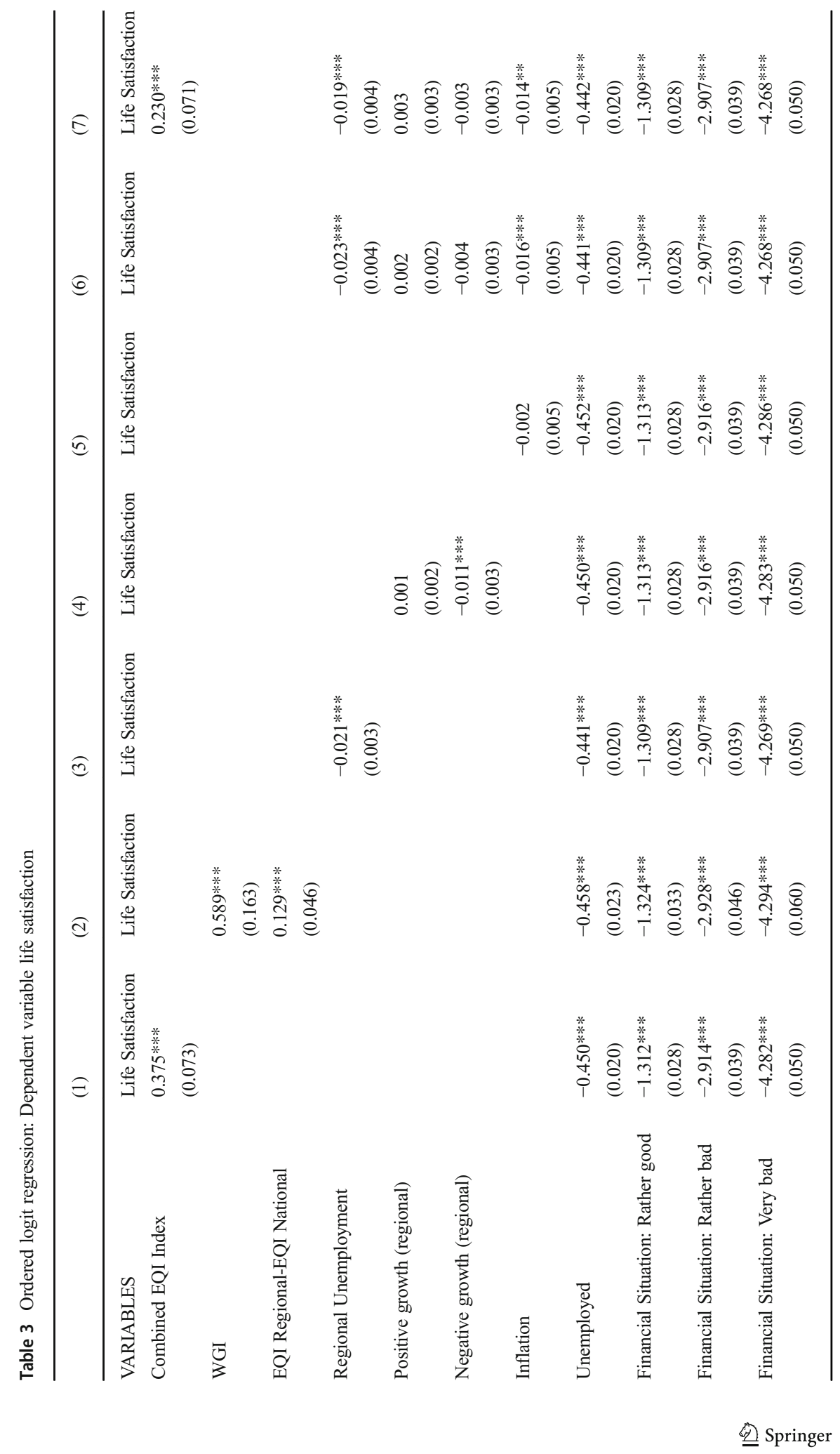




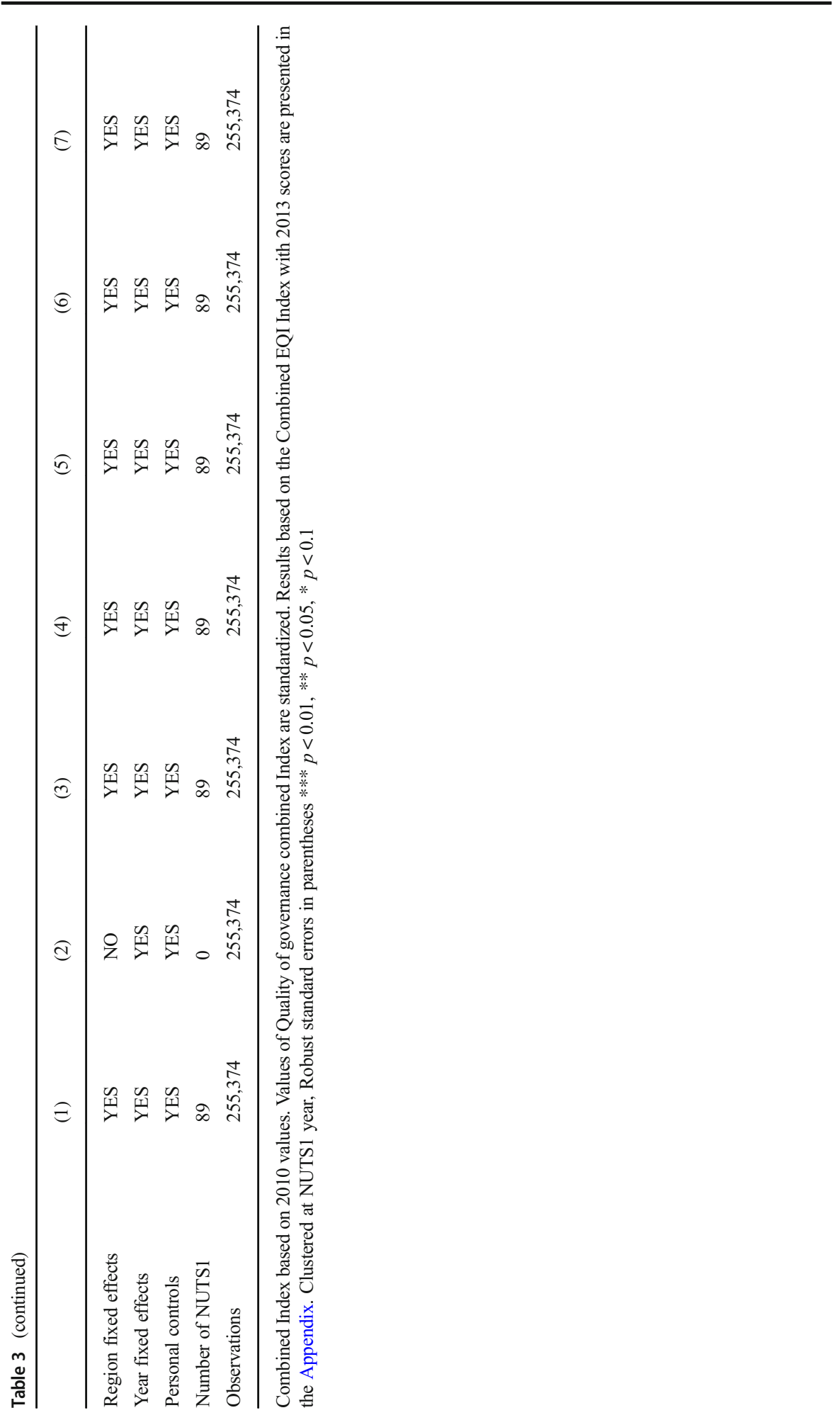

\section{黑 Springer}


persistent negative influence on life satisfaction, as suggested in the literature. Negative growth loses its significance when controlling for quality of governance and the other macroeconomic factors. In contrast, the association between inflation and subjective well-being becomes statistically significant after controlling for regional quality of governance and the other macroeconomic factors (Table 3, Column 7). When we turn to the individual components of unemployment and income, we find, in line with the existing literature, that negative personal circumstances are negatively associated with subjective well-being in that unemployed individuals and individuals with a worse financial situation report significantly lower subjective well-being scores.

Turning to the main focus of the paper, Table 4 tests the mitigating effect of regional quality of governance. Although regional unemployment has a negative effect on life satisfaction, this negative effect disappears in the presence of high quality of governance (Column 1). At the same time, the interaction effects between negative growth and regional quality of governance (Table 4, Column 3 ) and inflation and regional quality of governance (Table 4, Column 3) are statistically insignificant.

With regard to the cross-level interactions (Table 4, Column 5), we find-in line with our expectations - that the effect of being in a bad financial situation is less severe in regions characterized by good governance. In contrast, the effect of being unemployed on subjective well-being is more negative in countries characterized by good governance. Although this result is surprising, one explanation offered in the literature is that countries with good governance are also characterized by lower levels of unemployment and that being unemployed has a less detrimental effect on subjective well-being if there is high unemployment in the immediate vicinity. An explanation for this is that when unemployment is the social norm, becoming unemployed has little effect on social status (Clark 2003). At the same time, a further analysis in which we examined how the interaction effect varied across welfare regimes revealed that the negative effect is primarily driven by regions with a Christian Democratic or Bismarckian welfare model (Austria, Belgium, France, Germany, and Luxembourg) and when adding an interaction. Bambra and Eikemo (2008) - who similarly found a large gap between self-reported health between employed and unemployed living in this welfare regime type-highlighted restricted access to social insurance benefits, the relatively short length of entitlement, and the stigma on unemployment originating from an emphasis on a male breadwinner model as potential reasons for this gap. However, more research is necessary to explain this finding.

Figure 2 presents the marginal effects of regional unemployment on the probability that individuals will belong to any of the four categories of the dependent variable life satisfaction (Outcome 1: Not at all satisfied, Outcome 2: Not very satisfied, Outcome 3: Fairly Satisfied, Outcome 4: Very Satisfied) with higher Combined EQI Index values. The decreasing marginal value of regional unemployment on the first three outcomes of life satisfaction (Outcome 1: Not at all satisfied, Outcome 2: Not very satisfied, Outcome 3: Fairly Satisfied Outcome 4: Very satisfied) indicates that individuals are less likely to report one of the aforementioned outcomes with increasing values of quality of governance. Therefore, higher values of regional unemployment in combination 


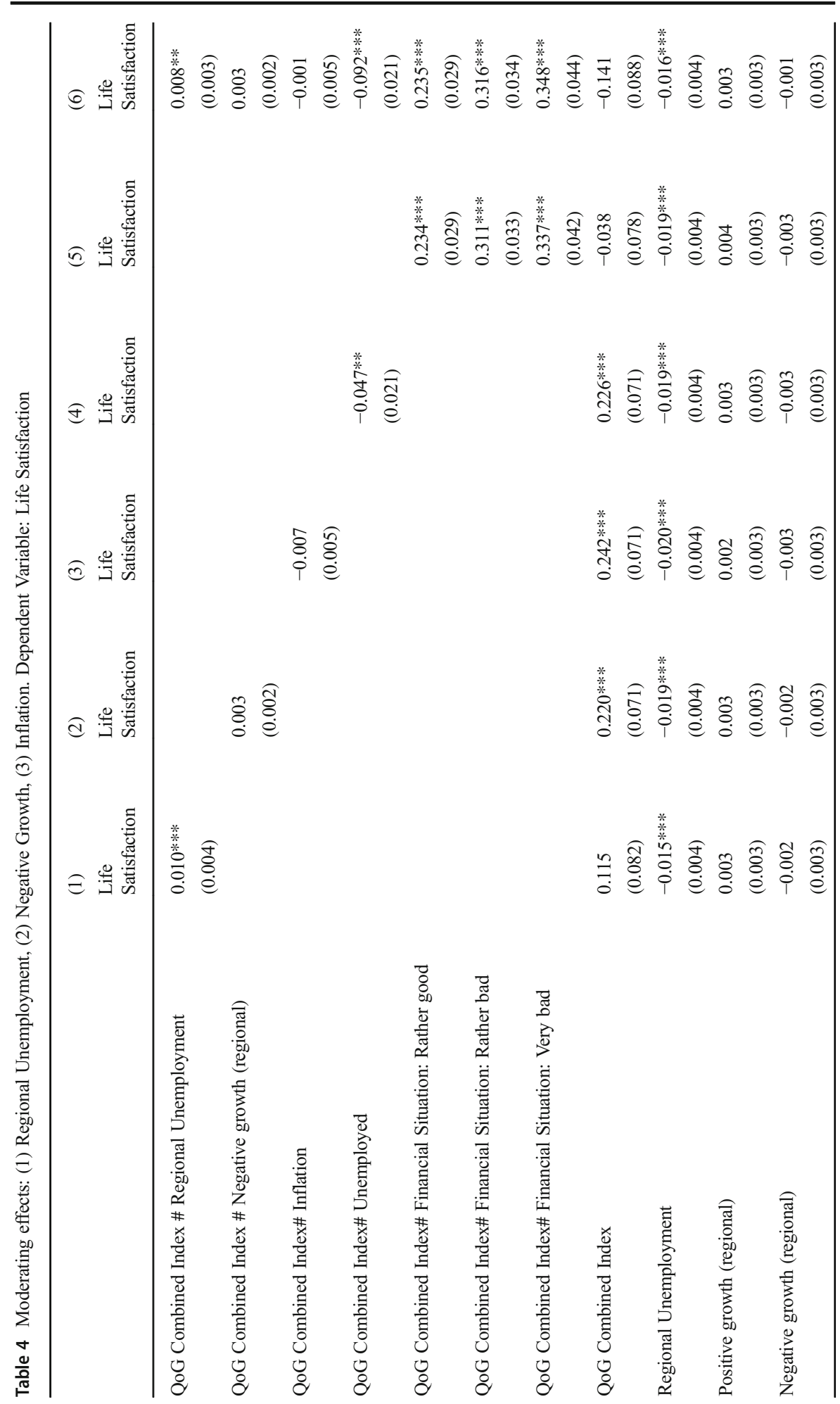




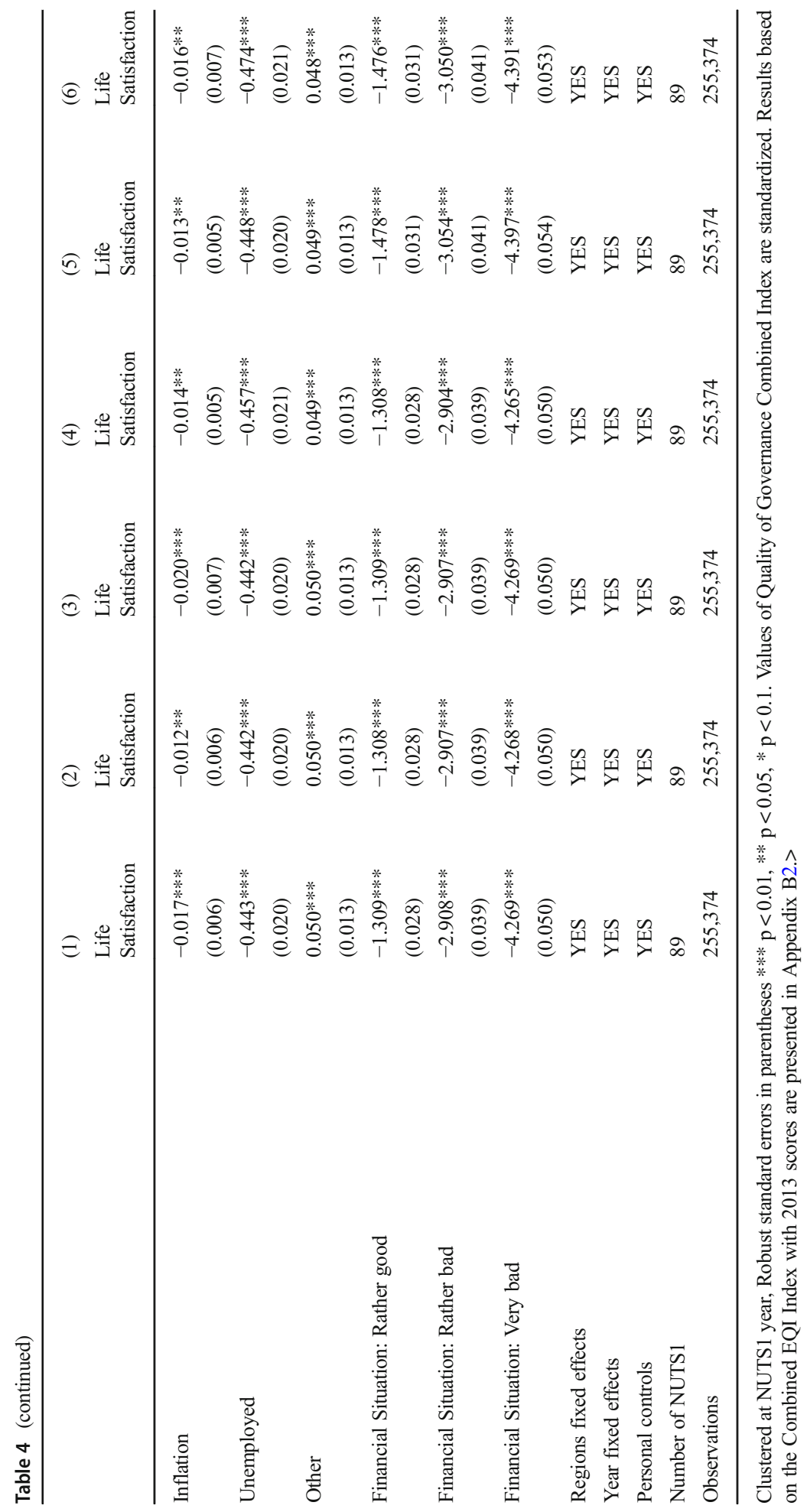


Average Marginal Effects of Unemployment_Regional with 95\% Cls

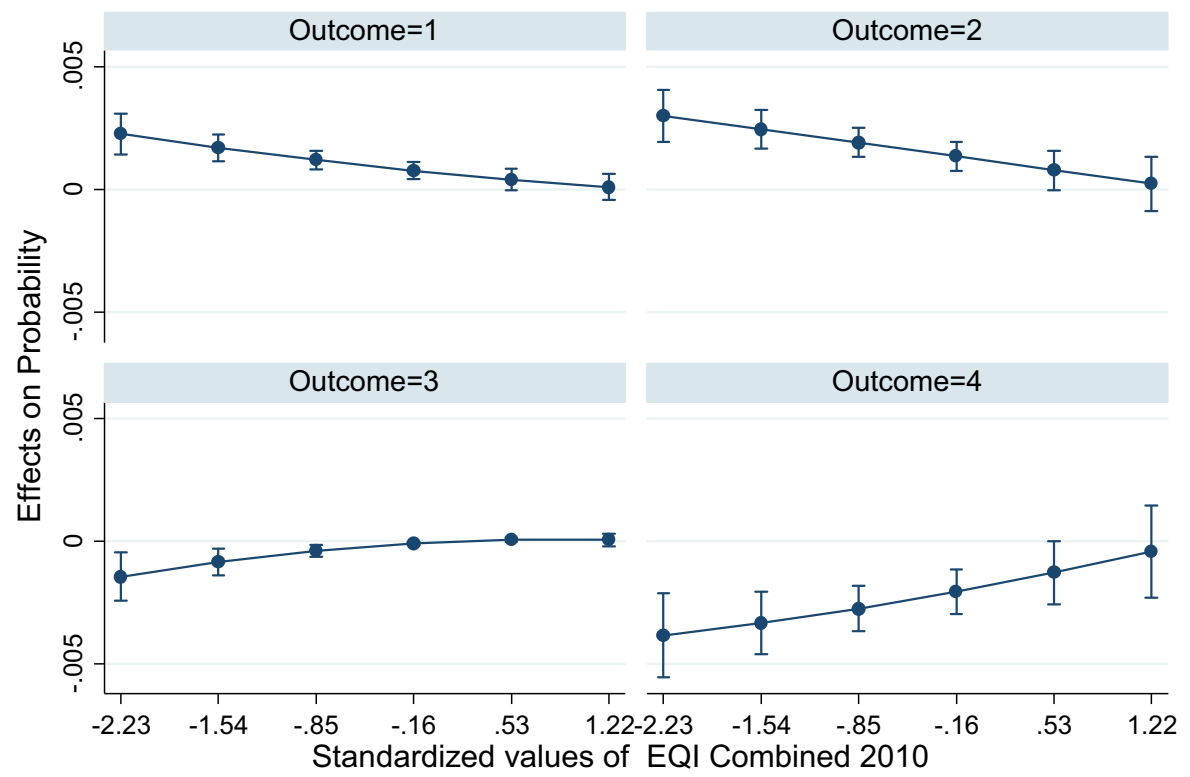

Fig. 2 Marginal Effects of Regional Unemployment by increasing values of QoG Combined: Outcome 1: Not at all satisfied, Outcome 2: Not very satisfied, Outcome 3: Fairly Satisfied, Outcome 4: Very satisfied

with increasing values of regional quality of governance have a strong positive association with the probability of reporting being very satisfied.

\section{Conclusions}

Surveys from international and European agencies have recorded considerable losses in happiness and life satisfaction scores during the Great Recession in Europe (Eurobarometer, Gallup). Previous research has shown that disproportionate changes in subjective well-being measures can been partly attributed to the different degrees to which the crisis hit European regions (WHR, 2013). We confirm previous findings on the negative impact of individual unemployment, financial difficulties, and regional indicators of unemployment, negative growth and inflation on life satisfaction amongst the European population during the Great Recession by accounting for the sub-national variation of the respective macroeconomic changes.

Our most remarkable findings, however, support that differences in quality of governance have a mitigating effect in times of crisis and that the additional gaps that are not explained by macroeconomic indicators are significantly predicted by these formal and predominantly localized institutions. The results demonstrate that increased regional unemployment and financial stress have a less aggravating effect on subjective well-being in regions characterized by a high quality of governance. These results support the capacity of quality of governance to buffer the negative effects of adverse macroeconomic conditions, most likely through generating trust and providing a safety net. Although these 
results are in line with earlier findings that trust and social capital moderate negative effects of the economic crisis, quality of governance indicators are less likely to be endogenous to life satisfaction compared with trust and social capital (Frey and Stutzer 2000a, b,; Dorn et al. 2007).

A final issue is the question of whether and how policies can be informed from the recent findings, a question that should be addressed with caution. We acknowledge that quality of governance is an important determinant of subjective appreciation of life. More importantly, quality of governance is a protective mechanism in terms of well-being during adversities, indicating that societies are less fragile in terms of well-being when there are indications that governments can properly and effectively function. With respect to public-policies, however, findings based on cross-national and sub-national variations in quality of governance might be less informative. Within regions, quality of governance is relatively stable over time, indicating that changes might not be easily implemented. For this reason, further research focusing on the impact of improvements in specific pillars of quality of governance at the regional level on subjective well-being is needed.

Acknowledgements The authors would like to thank an anonymous reviewer and participants of the ISQOLS Annual Conference in Seoul for useful feedback on an earlier version of this paper. Funding support by JPI Urban Europe project 'Resilient Cities: Industrial Network and Institutional perspectives on Economic Growth and Well-Being (grant 438-13-406)' is acknowledged by Martijn Burger, Spyridon Stavropoulos and Frank van Oort.

\section{Appendix 1}

Table 5 Average regional GDP growth, combined EQI Index, 2005-2014

\begin{tabular}{llllll}
\hline NUTS1 & $\begin{array}{l}\text { Regional } \\
\text { GDP } \\
\text { Growth }\end{array}$ & $\begin{array}{l}\text { Combined EQI } \\
2010\end{array}$ & NUTS1 & $\begin{array}{l}\text { Regional } \\
\text { GDP } \\
\text { Growth }\end{array}$ & $\begin{array}{l}\text { Combined } \\
\text { EQI 2010 }\end{array}$ \\
\hline AT1 & 3.04 & 1.18 & & 3.36 & 0.73 \\
AT2 & 2.72 & 0.71 & FR7 & 2.62 & 0.08 \\
AT3 & 3.01 & 0.91 & FR8 & 3.31 & 0.80 \\
BE1 & -1.66 & -0.96 & UKC/UKD/UKE & -16.89 & 0.66 \\
BE2 & 3.73 & 1.23 & UKF/UKG/UKH & -14.30 & 0.52 \\
BE3 & 1.97 & -0.26 & UKI/UKJ & 4.75 & 1.06 \\
DE1 & 3.16 & 1.14 & $\mathbf{U K K}$ & 3.56 & 0.58 \\
DE2 & 2.03 & 0.50 & $\mathbf{U K L}$ & 8.19 & 1.28 \\
DE3 & 4.61 & 0.97 & $\mathbf{U K M}$ & 5.80 & 0.80 \\
DE4 & 2.37 & 1.14 & $\mathbf{U K N}$ & -8.09 & -0.33 \\
DE5 & 2.17 & 1.10 & $\mathbf{E L 3}$ & -5.13 & -1.02 \\
DE6 & 2.56 & 0.89 & $\mathbf{E L 4}$ & -2.42 & -2.22
\end{tabular}


Table 5 (continued)

\begin{tabular}{|c|c|c|c|c|c|}
\hline NUTS1 & $\begin{array}{l}\text { Regional } \\
\text { GDP } \\
\text { Growth }\end{array}$ & $\begin{array}{l}\text { Combined EQI } \\
2010\end{array}$ & NUTS1 & $\begin{array}{l}\text { Regional } \\
\text { GDP } \\
\text { Growth }\end{array}$ & $\begin{array}{l}\text { Combined } \\
\text { EQI } 2010\end{array}$ \\
\hline DE7 & 2.42 & 0.56 & EL6 & -3.10 & -1.68 \\
\hline DE8 & 3.54 & 0.84 & IE0 & -2.47 & 0.66 \\
\hline DE9 & 2.41 & 0.93 & ITC & -2.45 & 0.22 \\
\hline DEA & 3.41 & 0.44 & ITH & 0.32 & 0.90 \\
\hline DEB & 2.14 & 0.67 & ITI & 3.22 & -0.49 \\
\hline DEC & 3.24 & 1.26 & ITF & 1.10 & -2.17 \\
\hline DED & 4.90 & 1.08 & ITG & -2.75 & -1.70 \\
\hline DEE & 1.60 & 0.81 & LU0 & 0.65 & 0.99 \\
\hline DEF & 3.01 & 1.63 & NL1 & 3.38 & 1.77 \\
\hline DEG & 1.07 & 1.60 & NL2 & 2.17 & 1.04 \\
\hline DK0 & -3.70 & 1.49 & NL3 & -0.24 & 1.18 \\
\hline ES1 & 6.19 & 0.54 & NL4 & 2.76 & 0.77 \\
\hline ES2 & 0.71 & 0.46 & PT0 & 4.43 & -0.18 \\
\hline ES3 & 6.95 & -0.33 & SE1 & 8.96 & 1.29 \\
\hline ES4 & 0.53 & -0.07 & SE2 & -17.73 & 1.46 \\
\hline ES5 & 0.00 & -0.37 & SE3 & 3.58 & 1.14 \\
\hline ES6 & -2.29 & -0.02 & CYO & -2.94 & -0.07 \\
\hline ES7 & 0.50 & 0.33 & CZ0 & -2.68 & -0.59 \\
\hline FI1 & 4.66 & 1.39 & EE0 & 17.36 & -0.14 \\
\hline FR1 & 0.39 & 0.47 & HU1 & 2.01 & -1.15 \\
\hline FR2 & 0.00 & 0.18 & HU2 & -1.16 & -0.47 \\
\hline FR3 & 0.81 & 0.50 & HU3 & 3.23 & -0.53 \\
\hline FR4 & 3.80 & 0.27 & LV0 & 21.79 & -0.81 \\
\hline FR5 & 3.49 & 0.88 & MT0 & 0.00 & 0.06 \\
\hline FR6 & 3.19 & 0.81 & PL1 & -13.39 & -0.75 \\
\hline PL2 & 14.06 & -1.06 & BG3 & 0.00 & -1.98 \\
\hline PL3 & 11.94 & -0.59 & BG4 & 1.59 & -1.17 \\
\hline PL4 & 4.81 & -0.44 & RO1 & 22.22 & -0.99 \\
\hline PL5 & 17.46 & -0.84 & RO2 & 3.57 & -1.86 \\
\hline PL6 & 15.79 & -0.78 & RO3 & 24.42 & -2.62 \\
\hline SK0 & 4.62 & -0.68 & RO4 & 22.73 & -1.73 \\
\hline SI0 & 1.67 & -0.20 & HRO & -0.96 & -1.28 \\
\hline LT0 & 14.86 & -0.86 & & & \\
\hline
\end{tabular}




\section{Appendix 2: Additional estimations}

Table 6 EQI 2013, Ordered logit regression: Dependent variable life satisfaction

\begin{tabular}{|c|c|c|c|c|c|c|}
\hline \multirow[t]{2}{*}{ Variables } & (1) & (2) & (3) & (4) & (5) & (6) \\
\hline & $\begin{array}{l}\text { Life } \\
\text { satisfaction }\end{array}$ & $\begin{array}{l}\text { Life } \\
\text { satisfaction }\end{array}$ & $\begin{array}{l}\text { Life } \\
\text { satisfaction }\end{array}$ & $\begin{array}{l}\text { Life } \\
\text { satisfaction }\end{array}$ & $\begin{array}{l}\text { Life } \\
\text { satisfaction }\end{array}$ & $\begin{array}{l}\text { Life } \\
\text { satisfaction }\end{array}$ \\
\hline \multirow[t]{2}{*}{ QoG Combined Index 2013} & $0.368 * * *$ & & & & & $0.226 * * *$ \\
\hline & $(0.072)$ & & & & & $(0.070)$ \\
\hline \multirow[t]{2}{*}{ Regional Unemployment } & & $-0.021 * * *$ & & & $-0.023 * * *$ & $-0.019 * * *$ \\
\hline & & $(0.003)$ & & & $(0.004)$ & $(0.004)$ \\
\hline \multirow[t]{2}{*}{ Positive growth (regional) } & & & 0.001 & & 0.002 & 0.003 \\
\hline & & & $(0.002)$ & & $(0.002)$ & $(0.003)$ \\
\hline \multirow[t]{2}{*}{ Negative growth (regional) } & & & $-0.011 * * *$ & & -0.004 & -0.003 \\
\hline & & & $(0.003)$ & & $(0.003)$ & $(0.003)$ \\
\hline \multirow[t]{2}{*}{ Inflation } & & & & -0.002 & $-0.016^{* * *}$ & $-0.014 * *$ \\
\hline & & & & $(0.005)$ & $(0.005)$ & $(0.005)$ \\
\hline \multirow[t]{2}{*}{ Unemployed } & $-0.450 * * *$ & $-0.441 * * *$ & $-0.450 * * *$ & $-0.452 * * *$ & $-0.441 * * *$ & $-0.442 * * *$ \\
\hline & $(0.020)$ & $(0.020)$ & $(0.020)$ & $(0.020)$ & $(0.020)$ & $(0.020)$ \\
\hline \multirow[t]{2}{*}{ Other } & $0.049 * * *$ & $0.050 * * *$ & $0.050 * * *$ & $0.050 * * *$ & $0.050 * * *$ & $0.050 * * *$ \\
\hline & $(0.013)$ & $(0.013)$ & $(0.013)$ & $(0.013)$ & $(0.013)$ & $(0.013)$ \\
\hline \multirow{2}{*}{$\begin{array}{l}\text { Financial Situation: } \\
\text { Rather good }\end{array}$} & $-1.312 * * *$ & $-1.309 * * *$ & $-1.313 * * *$ & $-1.313^{* * *}$ & $-1.309^{* * *}$ & $-1.309 * * *$ \\
\hline & $(0.028)$ & $(0.028)$ & $(0.028)$ & $(0.028)$ & $(0.028)$ & $(0.028)$ \\
\hline \multirow{2}{*}{$\begin{array}{l}\text { Financial Situation: } \\
\text { Rather bad }\end{array}$} & $-2.914 * * *$ & $-2.907 * * *$ & $-2.916^{* * * *}$ & $-2.916^{* * *}$ & $-2.907 * * *$ & $-2.907 * * *$ \\
\hline & $(0.039)$ & $(0.039)$ & $(0.039)$ & $(0.039)$ & $(0.039)$ & $(0.039)$ \\
\hline \multirow{2}{*}{$\begin{array}{l}\text { Financial Situation: } \\
\text { Very bad }\end{array}$} & $-4.282 * * *$ & $-4.269 * * *$ & $-4.283 * * *$ & $-4.286^{* * *}$ & $-4.268 * * *$ & $-4.268 * * *$ \\
\hline & $(0.050)$ & $(0.050)$ & $(0.050)$ & $(0.050)$ & $(0.050)$ & $(0.050)$ \\
\hline Regions fixed effects & YES & YES & YES & YES & YES & YES \\
\hline Year fixed effects & YES & YES & YES & YES & YES & YES \\
\hline Personal controls & YES & YES & YES & YES & YES & YES \\
\hline Number of NUTS1 & 89 & 89 & 89 & 89 & 89 & 89 \\
\hline \multirow[t]{2}{*}{ Constant cut 1} & $-6.153^{* * *}$ & $-6.610 * * *$ & $-6.464 * * *$ & $-6.484 * * *$ & $-6.641 * * *$ & $-6.409 * * *$ \\
\hline & $(0.094)$ & $(0.075)$ & $(0.073)$ & $(0.072)$ & $(0.081)$ & $(0.106)$ \\
\hline \multirow[t]{2}{*}{ Constant cut 2} & $-3.924 * * *$ & $-4.380 * * *$ & $-4.236 * * *$ & $-4.256^{* * *}$ & $-4.411 * * *$ & $-4.178 * * *$ \\
\hline & $(0.088)$ & $(0.070)$ & $(0.066)$ & $(0.066)$ & $(0.076)$ & $(0.102)$ \\
\hline \multirow[t]{2}{*}{ Constant cut 3} & $-0.333 * * *$ & $-0.788 * * *$ & $-0.646^{* * *}$ & $-0.666^{* * *}$ & $-0.819 * * *$ & $-0.586 * * *$ \\
\hline & $(0.086)$ & $(0.063)$ & $(0.060)$ & $(0.061)$ & $(0.070)$ & $(0.098)$ \\
\hline Observations & 255,374 & 255,374 & 255,374 & 255,374 & 255,374 & 255,374 \\
\hline
\end{tabular}

Clustered at NUTS1 year, Robust standard errors in parentheses *** $\mathrm{p}<0.01, * * \mathrm{p}<0.05, * \mathrm{p}<0.1$. Combined Index based on 2010 values. Values of Quality of governance combined Index are standardized 
Table 7 EQI 2013, Moderation effects: Ordered logit regression: Dependent variable life satisfaction

\begin{tabular}{|c|c|c|c|c|c|c|}
\hline \multirow[t]{2}{*}{ Variables } & (1) & (2) & (3) & (4) & (5) & (6) \\
\hline & $\begin{array}{l}\text { Life } \\
\text { satisfaction }\end{array}$ & $\begin{array}{l}\text { Life } \\
\text { satisfaction }\end{array}$ & $\begin{array}{l}\text { Life } \\
\text { satisfaction }\end{array}$ & $\begin{array}{l}\text { Life } \\
\text { satisfaction }\end{array}$ & $\begin{array}{l}\text { Life } \\
\text { satisfaction }\end{array}$ & $\begin{array}{l}\text { Life } \\
\text { satisfaction }\end{array}$ \\
\hline $\begin{array}{l}\text { QoG Combined Index } 2013 \text { \# } \\
\text { Regional Unemployment }\end{array}$ & $\begin{array}{l}0.013 * * * \\
(0.004)\end{array}$ & & & & & $\begin{array}{l}0.013 * * * \\
(0.004)\end{array}$ \\
\hline $\begin{array}{c}\text { QoG Combined Index } 2013 \text { \# } \\
\text { Negative growth (regional) }\end{array}$ & & $\begin{array}{l}0.004 \\
(0.002)\end{array}$ & & & & $\begin{array}{l}0.003 \\
(0.002)\end{array}$ \\
\hline $\begin{array}{l}\text { QoG Combined Index } 2013 \text { \# } \\
\text { Inflation }\end{array}$ & & & $\begin{array}{l}-0.006 \\
(0.005)\end{array}$ & & & $\begin{array}{l}0.002 \\
(0.005)\end{array}$ \\
\hline $\begin{array}{l}\text { QoG Combined Index } 2013 \text { \# } \\
\text { Unemployed }\end{array}$ & & & & $\begin{array}{l}-0.038^{*} \\
(0.023)\end{array}$ & & $\begin{array}{l}-0.085^{* * * *} \\
(0.023)\end{array}$ \\
\hline $\begin{array}{l}\text { QoG Combined Index } 2013 \text { \# } \\
\text { Other }\end{array}$ & & & & $\begin{array}{l}0.028 * * \\
(0.012)\end{array}$ & & $\begin{array}{l}0.018 \\
(0.012)\end{array}$ \\
\hline $\begin{array}{l}\text { QoG Combined Index } 2013 \text { \# } \\
\text { Financial Situation: } \\
\text { Rather good }\end{array}$ & & & & & $\begin{array}{l}0.250 * * * \\
(0.027)\end{array}$ & $\begin{array}{l}0.251 * * * \\
(0.027)\end{array}$ \\
\hline $\begin{array}{l}\text { QoG Combined Index } 2013 \text { \# } \\
\text { Financial Situation: } \\
\text { Rather bad }\end{array}$ & & & & & $\begin{array}{l}0.333 * * * \\
(0.031)\end{array}$ & $\begin{array}{l}0.337 * * * \\
(0.032)\end{array}$ \\
\hline $\begin{array}{l}\text { QoG Combined Index } 2013 \text { \# } \\
\text { Financial Situation: } \\
\text { Very bad }\end{array}$ & & & & & $\begin{array}{l}0.356 * * * \\
(0.041)\end{array}$ & $\begin{array}{l}0.362 * * * \\
(0.042)\end{array}$ \\
\hline QoG Combined Index 2013 & $\begin{array}{l}0.074 \\
(0.082)\end{array}$ & $\begin{array}{l}0.216^{* * *} \\
(0.069)\end{array}$ & $\begin{array}{l}0.235 * * * \\
(0.070)\end{array}$ & $\begin{array}{l}0.218 * * * \\
(0.070)\end{array}$ & $\begin{array}{l}-0.058 \\
(0.075)\end{array}$ & $\begin{array}{l}-0.216^{* * *} \\
(0.089)\end{array}$ \\
\hline Regional Unemployment & $\begin{array}{l}-0.013 * * * \\
(0.004)\end{array}$ & $\begin{array}{l}-0.019 * * * \\
(0.004)\end{array}$ & $\begin{array}{l}-0.019 \text { *** } \\
(0.004)\end{array}$ & $\begin{array}{l}-0.019 * * * \\
(0.004)\end{array}$ & $\begin{array}{l}-0.019 * * * \\
(0.004)\end{array}$ & $\begin{array}{l}-0.013 * * * \\
(0.004)\end{array}$ \\
\hline Positive growth (regional) & $\begin{array}{l}0.002 \\
(0.002)\end{array}$ & $\begin{array}{l}0.003 \\
(0.003)\end{array}$ & $\begin{array}{l}0.002 \\
(0.003)\end{array}$ & $\begin{array}{l}0.003 \\
(0.003)\end{array}$ & $\begin{array}{l}0.004 \\
(0.003)\end{array}$ & $\begin{array}{l}0.003 \\
(0.003)\end{array}$ \\
\hline Negative growth (regional) & $\begin{array}{l}-0.002 \\
(0.003)\end{array}$ & $\begin{array}{l}-0.002 \\
(0.003)\end{array}$ & $\begin{array}{l}-0.003 \\
(0.003)\end{array}$ & $\begin{array}{l}-0.003 \\
(0.003)\end{array}$ & $\begin{array}{l}-0.003 \\
(0.003)\end{array}$ & $\begin{array}{l}-0.001 \\
(0.003)\end{array}$ \\
\hline Inflation & $\begin{array}{l}-0.018 * * * \\
(0.005)\end{array}$ & $\begin{array}{l}-0.012 * * \\
(0.006)\end{array}$ & $\begin{array}{l}-0.019^{* *} \\
(0.007)\end{array}$ & $\begin{array}{l}-0.014 * * \\
(0.005)\end{array}$ & $\begin{array}{l}-0.013 * * \\
(0.005)\end{array}$ & $\begin{array}{l}-0.013 * \\
(0.007)\end{array}$ \\
\hline Unemployed & $\begin{array}{l}-0.443 * * * \\
(0.020)\end{array}$ & $\begin{array}{l}-0.442 * * * \\
(0.020)\end{array}$ & $\begin{array}{l}-0.442^{* * *} \\
(0.020)\end{array}$ & $\begin{array}{l}-0.456^{* * * *} \\
(0.021)\end{array}$ & $\begin{array}{l}-0.448^{* * * *} \\
(0.020)\end{array}$ & $\begin{array}{l}-0.474 * * * \\
(0.021)\end{array}$ \\
\hline Other & $\begin{array}{l}0.050 * * * \\
(0.013)\end{array}$ & $\begin{array}{l}0.050 * * * \\
(0.013)\end{array}$ & $\begin{array}{l}0.050 * * * \\
(0.013)\end{array}$ & $\begin{array}{l}0.049 * * * \\
(0.013)\end{array}$ & $\begin{array}{l}0.049 * * * \\
(0.013)\end{array}$ & $\begin{array}{l}0.048 * * * \\
(0.013)\end{array}$ \\
\hline $\begin{array}{l}\text { Financial Situation: } \\
\text { Rather good }\end{array}$ & $\begin{array}{l}-1.309^{* * *} \\
(0.028)\end{array}$ & $\begin{array}{l}-1.309^{* * * *} \\
(0.028)\end{array}$ & $\begin{array}{l}-1.309^{* * *} \\
(0.028)\end{array}$ & $\begin{array}{l}-1.308^{* * *} \\
(0.028)\end{array}$ & $\begin{array}{l}-1.494 * * * \\
(0.030)\end{array}$ & $\begin{array}{l}-1.493 * * * \\
(0.030)\end{array}$ \\
\hline $\begin{array}{l}\text { Financial Situation: } \\
\text { Rather bad }\end{array}$ & $\begin{array}{l}-2.909^{* * * *} \\
(0.039)\end{array}$ & $\begin{array}{l}-2.907 * * * \\
(0.039)\end{array}$ & $\begin{array}{l}-2.907 * * * \\
(0.039)\end{array}$ & $\begin{array}{l}-2.904 * * * \\
(0.039)\end{array}$ & $\begin{array}{l}-3.068 * * * \\
(0.040)\end{array}$ & $\begin{array}{l}-3.065^{* * *} \\
(0.040)\end{array}$ \\
\hline $\begin{array}{l}\text { Financial Situation: } \\
\text { Very bad }\end{array}$ & $\begin{array}{l}-4.269^{* * * *} \\
(0.050)\end{array}$ & $\begin{array}{l}-4.268 * * * \\
(0.050)\end{array}$ & $\begin{array}{l}-4.269^{* * * *} \\
(0.050)\end{array}$ & $\begin{array}{l}-4.265^{* * *} \\
(0.050)\end{array}$ & $\begin{array}{l}-4.412 * * * \\
(0.054)\end{array}$ & $\begin{array}{l}-4.407 * * * \\
(0.053)\end{array}$ \\
\hline Regions fixed effects & YES & YES & YES & YES & YES & YES \\
\hline Year fixed effects & YES & YES & YES & YES & YES & YES \\
\hline
\end{tabular}


Table 7 (continued)

\begin{tabular}{lllllll}
\hline Variables & $(1)$ & $(2)$ & $(3)$ & $(4)$ & $(5)$ & $(6)$ \\
& $\begin{array}{l}\text { Life } \\
\text { satisfaction }\end{array}$ & $\begin{array}{l}\text { Life } \\
\text { satisfaction }\end{array}$ & $\begin{array}{l}\text { Life } \\
\text { satisfaction }\end{array}$ & $\begin{array}{l}\text { Life } \\
\text { satisfaction }\end{array}$ & $\begin{array}{l}\text { Life } \\
\text { satisfaction }\end{array}$ & $\begin{array}{l}\text { Life } \\
\text { satisfaction }\end{array}$ \\
\hline Personal controls & YES & YES & YES & YES & YES & YES \\
Number of NUTS1 & 89 & 89 & 89 & 89 & 89 & 89 \\
Constant cut1 & $-6.442 * * *$ & $-6.417 * * *$ & $-6.425 * * *$ & $-6.408 * * *$ & $-6.600 * * *$ & $-6.627 * * *$ \\
& $(0.103)$ & $(0.106)$ & $(0.106)$ & $(0.106)$ & $(0.106)$ & $(0.104)$ \\
Constant cut2 & $-4.209 * * *$ & $-4.186 * * *$ & $-4.194 * * *$ & $-4.178 * * *$ & $-4.359 * * *$ & $-4.385 * * *$ \\
& $(0.099)$ & $(0.102)$ & $(0.101)$ & $(0.102)$ & $(0.102)$ & $(0.100)$ \\
Constant cut3 & $-0.617 * * *$ & $-0.593 * * *$ & $-0.602 * * *$ & $-0.585 * * *$ & $-0.766 * * *$ & $-0.791 * * *$ \\
Observations & $(0.095)$ & $(0.097)$ & $(0.098)$ & $(0.098)$ & $(0.097)$ & $(0.096)$ \\
\hline
\end{tabular}

Clustered at NUTS1 year, Robust standard errors in parentheses *** $\mathrm{p}<0.01$, ** $\mathrm{p}<0.05, * \mathrm{p}<0.1$. Combined Index based on 2010 values. Values of Quality of governance combined Index are standardized

Open Access This article is distributed under the terms of the Creative Commons Attribution 4.0 International License (http://creativecommons.org/licenses/by/4.0/), which permits unrestricted use, distribution, and reproduction in any medium, provided you give appropriate credit to the original author(s) and the source, provide a link to the Creative Commons license, and indicate if changes were made.

\section{References}

Acemoglu, D., \& Johnson, S. (2005). Unbundling institutions. Journal of Political Economy, 113(5), 949-995. Acemoglu, D., \& Robinson, J. A. (2012). Why nations fail: The origins of power, prosperity, and poverty.

Alvarez-Diaz, A., Gonzalez, L., \& Radcliff, B. (2010). The politics of happiness: On the political determinants of quality of life in the American states. The Journal of Politics, 72(3), 894-905.

Arampatzi, E., Burger, M. J., \& Veenhoven, R. (2015). Financial distress and happiness of employees in times of economic crisis. Applied Economics Letters, 22(3), 173-179.

Arampatzi, E., Burger, M. J., Stavropoulos, S., \& Tay, L. (2018). The role of positive expectations for resilience to adverse events: Subjective well-being before, during and after the Greek bailout referendum. Working Paper, Erasmus University Rotterdam.

Arbia, G., Battisti, M., \& Di Vaio, G. (2010). Institutions and geography: Empirical test of spatial growth models for European regions. Economic Modelling, 27(1), 12-21.

Bambra, C., \& Eikemo, T. (2008). Welfare state regimes, unemployment and health: A comparative study of the relationship between unemployment and self-reported health in 23 European countries. Journal of Epidemiology \& Community Health, jech-2008.

Bjørnskov, C. (2014). Do economic reforms alleviate subjective well-being losses of economic crises? Journal of Happiness Studies, 15(1), 163-182.

Brenner, M. H. (1977). Health costs and benefits of economic policy. International Journal of Health Services, 7(4), 581-623.

Burger, M. (2015). Gross urban happiness. BRICS Magazine.

Carr, E., \& Chung, H. (2014). Employment insecurity and life satisfaction: The moderating influence of labour market policies across Europe. Journal of European Social Policy, 24(4), 383-399.

Charron, N., Lapuente, V., Rothstein, B., Varraish, A., Hernandez, M., Veisari, L. K., \& Popovski, D. (2011). Measuring quality of government and sub-national variation. Report for the EU Commission of Regional Development, European Commission. Directorate-general regional policy. 
Charron, N., Dijkstra, L., \& Lapuente, V. (2014). Regional governance matters: Quality of government within European Union member states. Regional Studies, 48(1), 68-90.

Clark, A. E. (2003). Unemployment as a social norm: Psychological evidence from panel data. Journal of Labor Economics, 21(2), 323-351.

Clark, A. E., \& Oswald, A. J. (1994). Unhappiness and unemployment. Economic Journal, 104, 648-659.

Cortinovis, N., Xiao, J., Boschma, R., \& van Oort, F. G. (2017). Quality of government and social capital as drivers of regional diversification in Europe. Journal of Economic Geography, 17(6), 1179-1208.

Crescenzi, R., \& Rodríguez-Pose, A. (2013). R\&D, socio-economic conditions, and regional innovation in the US. Growth and Change, 44(2), 287-320.

De Neve, J. E., Ward, G. W., De Keulenaer, F., Van Landeghem, B., Kavetsos, G., \& Norton, M. I. (2017). The asymmetric experience of positive and negative economic growth: Global evidence using subjective wellbeing data.

Deaton, A. (2011). The financial crisis and the well-being of America. In Investigations in the economics of aging (pp. 343-368). University of Chicago Press.

Di Tella, R., MacCulloch, R. J., \& Oswald, A. J. (2001). Preferences over inflation and unemployment: Evidence from surveys of happiness. The American Economic Review, 91(1), 335-341.

Di Tella, R., MacCulloch, R. J., \& Oswald, A. J. (2003). The macroeconomics of happiness. The Review of Economics and Statistics, 85(4), 809-827.

Dorn, D., Fischer, J., Kirchgassner, G., \& Sousa-Poza, A. (2007). Direct democracy and life satisfaction revisited: New evidence for Switzerland. Journal of Happiness Studies.

Easterlin, R. A. (1974). Does economic growth improve the human lot? Some empirical evidence. Nations and households in economic growth, 89, 89-125.

European Commission (2010) Europe 2020: A strategy for smart, sustainable and inclusive growth, Brussels.

Fordyce, W. E. (1988). Pain and suffering: A reappraisal. American Psychologist, 43(4), 276-283.

Freeman, R. B. (1978). Job satisfaction as an economic variable. American Economic Review, 68, $135-141$.

Frey, B. S., \& Stutzer, A. (2000a). Happiness prospers in democracy. Journal of Happiness Studies, 1(1), 79102.

Frey, B. S., \& Stutzer, A. (2000b). Happiness, economy and institutions. Economic Journal, 110, 918-938.

Frey, B. S., \& Stutzer, A. (2002). What can economists learn from happiness research? Journal of Economic Literature, 40, 402-435.

Gonza, G., \& Burger, A. (2017). Subjective well-being during the 2008 economic crisis: Identification of mediating and moderating factors. Journal of Happiness Studies, 18(6), 1763-1797.

Gudmundsdottir, D. G. (2013). The impact of economic crisis on happiness. Social Indicators Research, $110(3), 1083-1101$.

Helliwell, J. F., \& Huang, H. (2008). How's your government? International evidence linking good government and well-being. British Journal of Political Science, 38(04), 595-619.

Helliwell, J. F., Huang, H., \& Wang, S. (2014). Social capital and well-being in times of crisis. Journal of Happiness Studies, 15(1), 145-162.

Helliwell, J. F., Layard, R., \& Sachs, J. (Eds.). (2015). World happiness report 2015. New York: Sustainable Development Solutions Network.

Kahneman, D., Wakker, P. P., \& Sarin, R. (1997). Back to Bentham? Explorations of experienced utility. The Quarterly Journal of Economics, 112, 375-405.

Kaufmann, D., Kraay, A., \& Mastruzzi, M. (2009). Governance matters VIII: Aggregate and individual indicators, 1996-2008 (p. 4978). World Bank Policy Research Paper.

Kaufmann, D., Kraay, A., \& Mastruzzi, M. (2011). The worldwide governance indicators: Methodology and analytical issues. Hague Journal on the Rule of Law, 3(2), 220-246.

Mikucka, M., Sarracino, F., \& Dubrow, J. K. (2017). When does economic growth improve life satisfaction? Multilevel analysis of the roles of social trust and income inequality in 46 countries, 1981-2012. World Development, 93, 447-459.

Mishler, W., \& Rose, R. (2001). What are the origins of political trust? Testing institutional and cultural theories in post-communist societies. Comparative Political Studies, 34(1), 30-62.

Morgan, R. (2018). Labor market policy and subjective well-being during the great recession. Working Paper, Minerva Schools at KGI.

Morrison, P. S., \& Weckroth, M. (2018). Human values, subjective well-being and the metropolitan region. Regional Studies, 52(3), 325-337.

O'Connor, K. J. (2017). Who suffered Most from the great recession? Happiness in the United States. RSF: The Russell Sage Foundation Journal of the Social Sciences, 3(3), 72-99.

Orviska, M., \& Hudson, J. (2003). Tax evasion, civic duty and the law abiding citizen. European Journal of Political Economy, 19(1), 83-102. 
Ott, J. C. (2010). Good governance and happiness in nations: Technical quality precedes democracy and quality beats size. Journal of Happiness Studies, 11(3), 353-368.

Pacek, A., \& Radcliff, B. (2008). Assessing the welfare state: The politics of happiness. Perspectives on Politics, 6(2), 267-277.

Primo, D. M., Jacobsmeier, M. L., \& Milyo, J. (2007). Estimating the impact of state policies and institutions with mixed-level data. State Politics \& Policy Quarterly, 7(4), 446-459.

Radcliff, B. (2001). Politics, markets, and life satisfaction: The political economy of human happiness. American Political Science Review, 95(4), 939-952.

Rajkumar, A. S., \& Swaroop, V. (2008). Public spending and outcomes: Does governance matter? Journal of Development Economics, 86(1), 96-111.

Rodríguez-Pose, A. (2013). Do institutions matter for regional development? Regional Studies, 47(7), 1034 1047.

Rodríguez-Pose, A., \& Di Cataldo, M. (2015). Quality of government and innovative performance in the regions of Europe. Journal of Economic Geography, 15(4), 673-706.

Rothstein, B., Samanni, M., \& Teorell, J. (2012). Explaining the welfare state: Power resources vs. the quality of government. European Political Science Review, 4(1), 1-28.

Spruk, R., \& Kešeljević, A. (2016). Institutional origins of subjective well-being: Estimating the effects of economic freedom on National Happiness. Journal of Happiness Studies, 17(2), 659-712.

Sterlacchini, A. (2008). R\&D, higher education and regional growth: Uneven linkages among European regions. Research Policy, 37(6-7), 1096-1107.

Stutzer, A., \& Frey, B. S. (2003). Institutions matter for procedural utility: An economic study of the impact of political participation possibilities. In R. Mudambi, P. Navarra, \& G. Sobbrio (Eds.), Economic welfare, international business and global institutional change.

Tay, L., Herian, M. N., \& Diener, E. (2014). Detrimental effects of corruption and subjective well-being whether, how, and when. Social Psychological and Personality Science, 5(7), 751-759.

Van Oort, F. G., Burger, M. J., Knoben, J., \& Raspe, O. (2012). Multilevel approaches and the firmagglomeration ambiguity in economic growth studies. Journal of Economic Surveys, 26(3), 468-491.

Veenhoven, R. (1984). Conditions of Happiness. Dordrecht. Boston: Reidel.

Voßemer, J., Gebel, M., Täht, K., Unt, M., Högberg, B., \& Strandh, M. (2017). The effects of unemployment and insecure jobs on well-being and health: The moderating role of labor market policies. Social Indicators Research, 1-29.

World Happiness Report. (2013). New York. NY: UN Sustainable Development Solutions Network.

Wulfgramm, M. (2014). Life satisfaction effects of unemployment in Europe: The moderating influence of labour market policy. Journal of European Social Policy, 24(3), 258-272.

Publisher's Note Springer Nature remains neutral with regard to jurisdictional claims in published maps and institutional affiliations. 